УДК 159.9:378/.811.111+37.09

DOI https://doi.org/10.26661/2310-4368/2021-2-7

\title{
ПСИХОЛОГО-ПЕДАГОГІЧНІ УМОВИ ФОРМУВАННЯ ІНШОМОВНОЇ КОМПЕТЕНЦІЇ СТУДЕНТІВ
}

\author{
Орлова Н. В. \\ магістрантка кафедри психологї, \\ психологічного факультету, \\ кандидат педагогічних наук, доиент, \\ дочент кафедри іноземних мов \\ Черкаський національний університет імені Б. Хмельницького \\ б-р Шевченка, 81, м. Черкаси, Україна \\ orcid.org/0000-0001-6228-0085 \\ orlanvla@ukr.net \\ Шавровська Н. В. \\ кандидат психологічних наук, доиент, \\ дочент кафедри психологіі \\ Черкаський національний університет імені Б. Хмельницького \\ б-р Шевченка, 81, м. Черкаси, Україна \\ orcid.org/0000-0003-1302-7168 \\ shavrovska.natalia@gmail.com
}

\begin{abstract}
Ключові слова: тривожність, ситуативна тривожність, запам'ятовування, методика «оберненого» навчання, ментальні карти, навчання іноземних мов, студенти немовних спеціальностей
\end{abstract}

Формування іншомовної компетенції студентів пов'язане 3 певними психологічними чинниками, що можуть гальмувати навчальний процес $\mathrm{i}$ демотивуватистудентів під час навчання, атакож психолого-педагогічними складовими, які здатні корегувати процес формування іншомовної компетенції. Визначення, вивчення і узагальнення природи і способів урахування впливу психологічних факторів на процес навчання іноземної мови і формування іншомовної компетенції в межах створення психологопедагогічних умов сприятиме не лише глибшому розумінню цих процесів, але й покращенню результатів. У статті було проаналізоване дослідження педагогічного впливу методів і форм роботи, впроваджених з урахуванням психологічних чинників формування іншомовної компетенції на якість формування лексичної компетенції як складової іншомовної компетенції в процесі навчання іноземних мов студентів немовних спеціальностей. Гіпотеза про те, що створення належних психолого-педагогічних умов 3 урахуванням у навчальному процесі психологічних чинників і використанням методики «оберненого» навчання і роботи 3 технікою ментального мапування у процесі навчання іноземної мови знижують рівень ситуативної тривожності і покращують успішність і результати навчання, була доведена позитивними результатами дослідження. Було показано, що студенти з експериментальної групи, які впродовж роботи над темою опрацьовували навчальний матеріал за умовами «оберненого» навчання, а також розробляли власні ментальні карти на базі тематичного лексичного матеріалу, продемонстрували зниження рівня ситуативної тривожності та кращу успішність і володіння матеріалом. В результаті дослідження було виявлено, що зменшення рівня ситуативної тривожності у студентів контрольної групи за середнім значенням склало лише 2,41, тоді коли у студентів експериментальної групи цей покажчик становив 10,22, що є суттєво більшим. Також, середнє значення тестової 
оцінки у студентів експериментальної групи виявилося вище на 0,6 бала, що свідчить про кращій загальний рівень опанування лексичного матеріалу і сформованості лексичної компетенції як складової іншомовної компетенції студентів немовних спеціальностей закладів вищої освіти. За результатами дослідження було підсумовано, що використання на заняттях з іноземної мови ментальних карт і впровадження методики «оберненого» навчання допоможе знизити рівень ситуативної тривожності на заняттях і покращити запам'ятовування й відтворення лексичного матеріалу, тим самим підвищуючи ефективність навчального процесу і результативність у формуванні як лексичної компетенції, так й іншомовної компетенції студентів немовних спеціальностей.

\title{
PSYCHOLOGICAL AND PEDAGOGICAL CONDITIONS FOR DEVELOPMENT OF STUDENTS' FOREIGN LANGUAGE COMPETENCE
}

\author{
Orlova N. V. \\ Postgraduate Student in Psychology, \\ Department of Psychology, \\ Ph. D. (Pedagogics), Associate Professor, \\ Foreign Languages Chair \\ Bohdan Khmelnytsky National University of Cherkasy \\ Shevchenko Boulevard, 81, Cherkasy, Ukraine \\ orcid.org/0000-0001-6228-0085 \\ orlanvla@ukr.net \\ Shavrovska N. V. \\ Ph. D. (Psychology), Associate Professor, \\ Department of Psychology \\ Bohdan Khmelnytsky National University of Cherkasy \\ Shevchenko Boulevard, 81, Cherkasy, Ukraine \\ orcid.org/0000-0003-1302-7168 \\ shavrovska.natalia@gmail.com
}

Key words: anxiety, state anxiety, memorisation,

"Flipped" learning, Mind Maps, foreign languages learning, students of non-linguistic study-fields
The formation of students' foreign language competence is associated with certain psychological factors that can inhibit the learning process and demotivate students during their studies, and psychological and pedagogical conditions that are able to adjust and improve the process of formation of foreign language competence. Defining, studying and generalising the nature and methods that consider the influence of psychological factors on the process of learning a foreign language and the formation of foreign language competence will contribute not only to a deeper understanding of these processes, but also to results improvement. The article analyses the research into the impact of teaching methods and forms of class activities employed by taking into account the psychological factors of foreign language competence formation on the quality of lexical competence as a component of foreign language competence in university students of non-linguistic study fields. The hypothesis that the creation of appropriate psychological and pedagogical conditions taking into account the psychological factors within the educational process and the use of the method of "flipped" learning and Mind mapping in the process of learning a foreign language reduce the level of state anxiety and improves academic performance and learning outcomes, was supported 
by positive research findings. The students from the experimental group, who processed the study material on the terms of "flipped" learning, as well as worked on creation of their own Mind maps based on thematic lexical material, demonstrated reduced state anxiety and better acquisition of material. As a result, it was found that the decrease in the level of state anxiety in students of the control group on average was only 2.41 , while the experimental group showed 10.22 , which is significantly higher. Furthermore, the average test score of the students from the experimental group was higher by 0.6 points, which indicates a better overall level of mastery of lexical material and the formation of lexical competence as part of the foreign language competence of university students of non-linguistic study fields. According to the results of the study, it can be concluded that the use of Mind maps during foreign language classes and the exposure to "flipped" learning will help reduce state anxiety and improve memorisation and retrieval of the lexical material. Thus, it will increase the efficiency of learning and effectiveness in forming both lexical competence and foreign language competence of university students of non-linguistic study fields.

Постановка проблеми: Сучасні вимоги до професійних функцій майбутніх фахівців включають не лише високий рівень професійних знань $\mathrm{i}$ навичок, але й поєднання бажання і здатності до подальшого вдосконалення професійних навичок, спроможність бути конкурентоздатним і мобільним фахівцем у сучасному інтегрованому світі, що обов'язково включає достатньо вільне володіння іноземною мовою (далі - IM) як фахового спрямування, так і загально розмовного регістра. Відомим фактом $\epsilon$ те, що низький рівень мобільності випускників українських закладів вищої освіти (далі - 3ВО) на ринку праці як в Україні, так і у світі в цілому є наслідком саме недостатніх знань IM, які надають студентам можливості, не лише пов'язані з майбутньою професійною діяльністю, але й актуальні на період навчання у ЗВО. Серед останніх варто виокремити участь у міжнародних навчальних програмах, програмах обміну, оформлення і успішне подання документів на отримання міжнародних грантів тощо.

Психолого-педагогічні умови формування ІК складаються 3 виокремлення психологічної складової, як-то психологічні чинники процесу формування IК, що впливають на якість формування IК, а також педагогічної складової, тобто визначення педагогічних підходів і технік для використання під час навчального процесу для збільшення його ефективності i, відповідно, покращення рівня сформованості ІК студентів ЗВО. Питання, що стосуються найдоречніших методів і підходів до навчання IM у ЗВО, залишаються актуальними вже тривалий час. Розробляючи методичні рекомендації щодо навчання IM, яке базується виключно на лінгвістичних i когнітивних засадах, педагоги можуть не врахувати важливі психологічні аспекти. Серед специфічних психологічних чинників, які познача- ються на успішності навчання IM, виокремлюють самооцінку, само-ефективність, рівні тривожності, екстраверсію, мотивацію, типи особистості й темпераменту [1, с. 322]. Тривожність як важлива складова процесу навчання IM щільно переплітається 3 якістю запам'ятовування іншомовного матеріалу. Американський дослідник тривожності Ч. Спілбергер виділяє дві їі форми - тривожність як стан (state anxiety) і як особистісну рису (trait anxiety) [2]. Тривожність, пов'язану з конкретною зовнішньою ситуацією, дослідник називає ситуативною, а ту, що є стабільною властивістю особистості, - особистісною. Ситуативна тривожність носить тимчасовий характер, через емоції викликані стресовими факторами навколишнього середовища, в тому числі фізіологічним збудженням i симптомами побоювання, занепокоєння і напруги. На відміну від ситуативної, особистісна тривожність відноситься до індивідуальних особливостей у схильності реагувати на загрозливі ситуації і часто визначається як характер особистості [2].

У студентів першого курсу немовних спеціальностей спостерігається відсутність інтересу до занять з IM. Серед причин визначають низьку базову підготовку з IM, через яку, як наслідок, з'являються очікування невдач, страх помилок, тривожність через відчуття неспроможності подолати психологічні бар'єри, що призводить до пасивності під час навчального процесу, прогулів заняття, а це в свою чергу ще більше знижує рівень знань студентів і підвищує рівень ситуативної тривожності, що продукує і поступово закріплює внутрішній спротив вивченню мови. Як наслідок, підпадає під подібний згубний або дебілітативний вплив [3] високого рівня ситуаційної тривожності і страждає процес опанування лексичного матеріалу як важливої складової процесу формування іншомовної компетенції (далі - ІК). 
Аналіз нешодавніх досліджень і публікацій: Основи поняття комунікативна компетенція і особливості іiі формування представлені у доробку Д. Гаймса [4]. Безпосередньо засадам процесу формування іншомовної компетенції приділяли увагу такі науковці як Н.А. Глуховська [5], І.Л. Онуфрісва і Л.А. Онуфрісва [6], О.О. Пантелєєва і Т.Є. Малєєва [7], Ю.І. Пассов [8] та інші. Вивченню тривожності приділяли увагу багато науковців. Е. Горвіц [3] з колегами спеціалізувалася на вивченні мовної та іншомовної тривожності, Ч. Спілбергер [2] досліджував феномен тривожності в ситуативній та особистісній формах. М. Айзенк [9] фокусувався на вивченні тривожності в контексті ії впливу на навчання і пам'ять. П. Макінтаєр і Р. Гарднер [10] вивчали вплив тривожності на когнітивні процеси під час вивчення другої мови, а також розробляли керівництво щодо створення академічного середовища 3 низьким рівнем тривожності. Проблематику впровадження «оберненого» навчання (Flipped learning) у закладах вищої освіти опрацьовують роботи С.Дж. Брейм [11] та інших. Щодо вивчення ролі ментальних карт, то серед досліджень і публікацій варто згадати наступні: А. Буран і А. Філюков у 2015 році досліджували використання техніки ментального мапування у процесі викладання IM студентами технічних 3ВО [12]; Н. Орлова вивчала місце i фасилітативний вплив ментального мапування (Mind Maps) на якість усного монологічного мовлення студентів немовних спеціальностей [13].

Аналіз досліджень і публікацій підтвердив необхідність вирішення проблематики створення психолого-педагогічних умов з урахуванням психологічних чинників і педагогічних підходів і технік для успішного формування як ІК взагалі, так і іiї лексичної складової у студентів немовних спеціальностей ЗВО.

Мета статті полягає у вивченні аспектів створення психолого-педагогічних умов формування ІК у студентів немовних спеціальностей ЗВО.

Виклад основного матеріалу дослідження: Під ІК розуміють вміння доречно і коректно користуватися IM в певних ситуаціях, яке охоплюе висловлення думок, бажань, прохань і намірів промовця. Також іншомовну компетенцію визначають як комплекс лінгвістичних і соціокультурних знань, умінь і здатностей, що реалізуються суб' єктом згідно 3 комунікативним завданням в іншомовному оточенні [14, с. 34]. В межах іншомовної компетенції Н. Пруднікова виділяє лінгвістичну, соціолінгвістичну й предметну компетенції $[15$, с. 13]. Ю. Федоренко виокремлює серед складових іншомовної компетенції наступні: мовленнєву, мовну, дискурсивну, стратегічну і соціокультурну компетенцію [16, с. 7]. Поняття
IК як змістовний компонент здатності людини до практичної діяльності 3 використанням IM визначається О.О. Пантелєєвою і Т.Є. Малєєвою як знання, навички, вміння і рівень володіння IM, тобто сукупність умінь, необхідних особі для виконання певної діяльності [7, с. 134-135].

В сучасних умовах іншомовна компетенція вважається складовою частиною професійної компетенції майбутнього фахівця. I згідно 3 Н.А. Глуховською, іншомовна компетенція фахової орієнтації полягає у вмінні користуватися іноземною мовою професійної спрямованості у контекстах, пов'язаних і з теперішньою академічною, і майбутньою професійною діяльністю студентів [5, с. 70].

Ключовим чинникам формування IК є продуктивне навчання IM, що буде відбуватися за належних психолого-педагогічних умов, а саме умов низької тривожності та ефективного запам'ятовування лексико-граматичного матеріалу [4] з застосуванням відповідних педагогічних технологій.

Невіддільною складовою ІК є лексична компетенція, адже без набуття останньої IK не може бути сформована. Згідно з Ю.І. Пассовим процес навчання іншомовної лексики відбувається поетапно і охоплює формування навичок роботи 3 лексичним матеріалом, поступово вдосконалення цих навичок і розвиток вмінь користуватися опанованими лексичними одиницями під час тематичного або, надалі, професійно орієнтованого мовлення [8, с. 115]. Таким чином, від рівня сприйняття нової лексичної одиниці залежить якість запам'ятовування, довго тривалість утримання в пам'яті, а також успішність подальшого відтворення. Отже, необхідно задіяти методи і форми роботи, що будуть стимулювати і заохочувати студентів активно використовувати доречні до навчальної ситуації зорові та слухові аналізатори для мобілізації уваги, мислення для ефективного процесу запам'ятовування і зменшувати рівень тривожності. Щодо використання соціально-психологічних стратегій, які мають на меті створення сприятливого академічного середовища, Н.В. Шавровська наголошує на активному залученні всіх учасників навчального процесу, виявленні позитивного безоціночного ставлення, уникнення категорійних суджень, підкріплення значущості кожного учасника навчального процесу $\mathrm{i}$ важливість індивідуальних результатів навчального процесу [17, с. 125].

Проблемні аспекти, що проявляються під час навчання IM студентами немовних спеціальностей 3ВО, охоплюють початково-низький рівень володіння IM, нерозуміння потреби в навчанні IM, переважно негативний попередній досвід у навчанні IM i, відповідно, наявну високу тривожність і низьку мотивацію до вивчення IM. Для 
зменшення впливу проблемних факторів важливо виокремити їх для усвідомлення викладачами, які зможуть розробити й впровадити ефективні методи навчання IM саме з урахуванням психологічних чинників.

Створення сприятливої атмосфери на заняттях для зниження дебілітативного впливу [3] тривожності, притаманному процесу вивчення IM за допомогою запровадження особистісно-гуманного підходу (методу «оберненого» навчання Flipped learning), створення доброзичливої атмосфери в дусі терпимості й прийняття, усвідомлення права на помилки в процесі навчання, а також тематичної орієнтації в бік фахових дисциплін, реалізуючи принцип професійної спрямованості навчання, буде сприяти підвищенню зацікавленості студентів у вивченні IM. Чи не найважливішою особливістю таких занять $\epsilon$ i те, що до навчального процесу залучаються усі без виключення студенти, що сприяє підвищенню загального відсотка успішності в групі [11].

Графічні організатори, як то ментальні карти (Mind Maps), спрямовані на систематизацію і структурування з використанням малюнків, опорних слів або фраз, слугуватимуть гнучким та ефективним інструментом для сприяння зняття мовного бар'єра, розвитку критичного і творчого мислення, служитимуть мнемонічними засобами для покращення запам'ятовування і відтворення іншомовної інформації, тим самим знижуючи рівень ситуативної тривожності під час вивчення IM [13, с. 152]. Як демонструють результати попередніх досліджень [18], переважну роль під час вербальної діяльності й мовлення, логічного, раціонального й аналітичного мислення має ліва півкуля, тоді як права півкуля відповідає за обробку складних стимулів.

Нами було зроблене припущення, що створення належних психолого-педагогічних умов, ураховуючи психологічні чинники, що включають особливості запам'ятовування і відтворення лексичного матеріалу, пов'язані з наявністю у студентів ситуативної тривожності, і педагогічних підходів і технік сприятимуть ефективності формування ІК студентів немовних спеціальностей ЗВО. Для доведення припущення були створені групи для проведення експерименту. Учасниками дослідження стали студенти I курсу психологічного факультету Черкаського національного університету імені Богдана Хмельницького. Загальна кількість учасників становила 44 осіб. Учасники були розподілені на дві групи: контрольна група (22 особи) та експериментальна група (22 особи). Bci учасники опрацьовували тему «Historical Schools of Thought in Psychology», наприкінці якої відбувся контроль сформованості ІК. На початку експерименту в обох групах був виміряний рівень ситуативної тривожності (Діагностика 1). Для цього була використана методика ШРОТ Спілбергера-Ханіна. За умовами дослідження контрольна група студентів працювала над темою у звичайних умовах проведення занять 3 використанням стандартних лінійних текстів і вправ, а експериментальна група опрацьовувала навчальний матеріал за умовами методики «оберненого» навчання 3 додатковими автентичними відеоматеріалами для опрацювання напередодні заняття, а також розробляла власні ментальні карти на базі тематичного лексичного матеріалу. По завершенню експерименту в кожній групі був повторно виміряний рівень ситуативної тривожності (Діагностика 2). Крім того було проведене тематичне тестування для виявлення рівня сформованості лексичної компетенції як складової ІК студентів.

Аналіз результатів Діагностики 1 контрольної групи дозволив виявити переважання високого рівня ситуативної тривожності, що склало $63,6 \%$ від загальної кількості студентів, 31,8\% студентів показали середній рівень ситуативної тривожності та лише 4,6\% продемонстрували низький рівень ситуативної тривожності. Показник середнього значення рівня ситуативної тривожності контрольної групи становив 46,41. Студентами експериментальної групи були продемонстровані наступні дані: переважна кількість студентів виявила середній рівень ситуативної тривожності $-59,1 \%$, високий рівень був показаний $36,4 \%$ членів групи і лише $4,5 \%$ студентів мали низький рівень ситуативної тривожності. Показник середнього значення рівня ситуативної тривожності контрольної групи становив 44,82.

За результатами пост-експериментальної Діагностики 2, були отримані наступні дані. Було виявлено, що серед студентів-членів контрольної групи переважає високий рівень ситуативної тривожності - 54,5\%, середній рівень показали $40,9 \%$ студентів, і сталі 4,6\% членів контрольної групи мали низький рівень ситуативної тривожності. Показник середнього значення рівня ситуативної тривожності за Діагностикою 2 у контрольної групи становив 44. За результатами Діагностики 2, проведеної в експериментальній групі, з'ясували, що серед студентів-членів експериментальної групи переважає середній рівень ситуативної тривожності і складає $63,6 \%$, низький рівень тривожності мають 27,3\% членів експериментальної групи, а високий рівень тривожності показали лише 9,1 \% студентів. Відповідно, показник середнього значення рівня ситуативної тривожності за Діагностикою 2 у контрольної групи становив 34,6 .

Після проведення контрольного тестування студенти контрольної групи показали задовільні результати в об'ємі знань та ступені володіння 


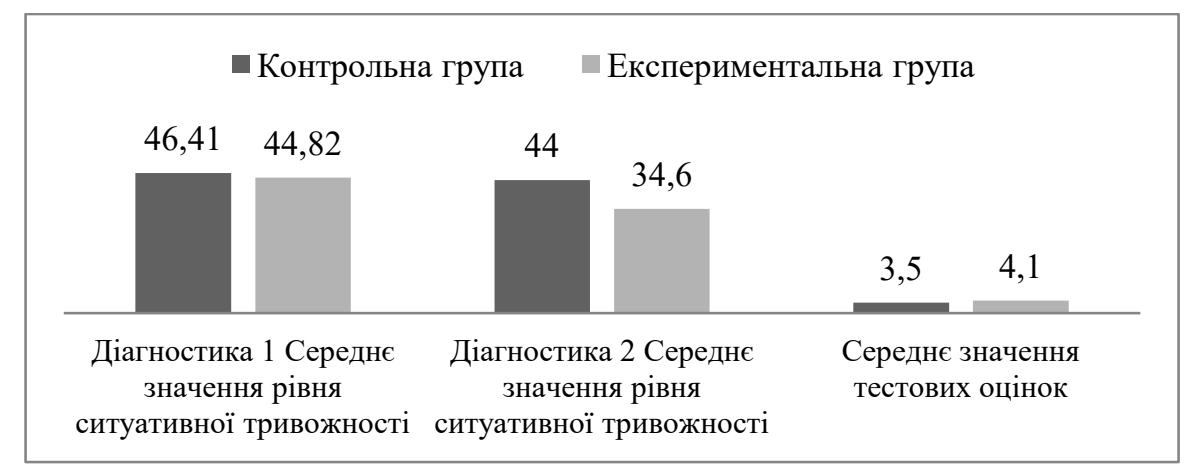

Діаграма 1. Порівняльні дані діагностик і тестових результатів контрольної та експериментальної груп

тематичним лексичним матеріалом: 4 особи отримали вищій бал - «відмінно», що склало $18,2 \%$, 5 осіб отримали оцінку «добре» і становили $22,7 \%$ від загальної кількості студентів, 13 осіб мали задовільну оцінку, що відповідає 59,1\%, проте осіб, які не впорались 3 тестуванням, не було.

В той час за успішністю засвоєння тематичного лексичного матеріалу з оцінкою «відмінно» в експериментальній групі 6 виявили осіб $(27,3 \%)$; «добре» - 9 осіб (40,9\%); «задовільно» - 7 осіб $(31,8 \%)$. В групі також відсутні студенти, які отримали незадовільну тестову оцінку.

Порівняльні дані по результатах підсумкового тестування, проведеного в контрольній та експериментальній групах демонструють, що застосовані методи «оберненого» навчання і робота 3 ментальними картами, сприяли кращому опануванню лексичного матеріалу. Адже у експериментальній групі оцінок «задовільно» отримало на 6 осіб менше, що складає 27,3\%, оцінки «добре» отримали на 4 особи, тобто на 18,2\%, більше, а кількість оцінок «відмінно» також більше на 2, що відповідає 9,1\%.

В результаті, як показано на діаграмі 1, видно, що зменшення рівня ситуативної тривожності у студентів контрольної групи за середнім значенням склало 2,41 , в той час, у студентів експериментальної групи цей покажчик становить 10,22. Крім того, середне значення тестової оцінки у студентів експериментальної групи також вище на 0,6 бала, що свідчить про кращій загальний рівень опанування лексичного матеріалу і сформованості лексичної компетенції як складової ІК студентів немовних спеціальностей ЗВО.

Описані результати доводять нашу гіпотезу про вплив на ефективність формування IК і зниження рівня ситуативної тривожності створення належних психолого-педагогічних умов 3 впровадженням методики «оберненого» навчання i використання ментального мапування під час опрацювання і вивчення лексичного тематичного матеріалу.

Висновки: Психолого-педагогічні умови формування ІК студентів ЗВО, що охоплюють психологічні чинники, як-то тривожність і особливості запам'ятовування, i педагогічні складові, тобто підходи і техніки, необхідно розглядати як важливі установки, ефективність запровадження яких надасть можливість покращення результатів, що сприятиме кар' єрному і особистісному зростанню через використання сучасної іншомовної інформації; можливість прямого контакту з науковцями та іноземними колегами-фахівцями, можливість продовження навчання або стажування за кордоном тощо. Метод «оберненого» навчання і ментальні карти помагають створенню сприятливої продуктивної атмосфери як під час занять з IM, так і під час автономної самостійної роботи студентів. Така організація навчання заохочує студентів до активності на заняттях завдяки зниженню рівня ситуативної тривожності, покращує результати навчання IM і підвищує рівень сформованості ІК. Проте, для подальшого вивчення проблематики урахування психологічних чинників в контексті створення психолого-педагогічних умов в процесі навчання IM було б доречно поглибити розуміння кореляції між самооцінкою студента та його навчанням і успішністю. Враховуючи поширення впровадження групових видів роботи і кооперативного навчання, необхідними також стають дослідження психолого-педагогічних аспектів групової динаміки у зв'язку з організацією продуктивної роботи на заняттях з IM для успішного формування ІК студентів ЗВО.

\section{ЛІТЕРАТУРА}

1. Орлова Н.В. Концепт тривожності як психологічний атрибут вивчення іноземної мови. Мовна особистість: лінгвістика і лінгводидактика. Київ-Черкаси, 2020. Вип. 5. С. 322-325.

2. Spielberger C. D. Anxiety: Current trends in theory and research. N.Y., 1972. Vol. 1. 268 p. 
3. Horwitz, E. Language anxiety and achievement. Annual Review of Applied Linguistics, 2001, 21, 112-126. doi:10.1017/S0267190501000071

4. Hymes, D. On Communicative Competence. C.J. Brumfit and K. Johnson (Eds.). The Communicative Approach to Language Teaching. London, 1979. P. 5-27

5. Глуховська Н.А. Формування іншомовної компетенції студентів технічних спеціальностей ВНЗ України аграрного профілю. Актуальні проблеми педагогіки, психології та професійної освіти. 2016. Вип.1. Електронний ресурс. Режим доступу: http://journals.uran.ua/apppfo

6. Онуфрієва І.Л., Онуфрієва Л.А. Психологічні особливості формування іншомовної комунікативної компетенції у студентів - майбутніх випускників немовних спеціальностей ВНЗ. Проблеми сучасної психології. Кам'янець-Подільській, 2011. Вип. 12. С. 727-739.

7. Пантелєєва О.О., Малєєва Т.Є. Формування іншомовної комунікативної компетенції студентів немовних спеціальностей. Духовність особистості: методологія, теорія, практика. Сєверодонецьк, 2019. № 1(88). С. 132-142.

8. Пассов Е.И. Коммуникативный метод обучения иноязычному говорению. 2-е изд. М.: Просвещение, 1991. 223 c.

9. Eysenck, M. W. Anxiety, learning, and memory: A reconceptualization. Journal of Research in Personality, Volume 13, Issue 4, 1979, P. 363-385, https://doi.org/10.1016/0092-6566(79)90001-1

10. MacIntyre, P. D., \& Gardner, R. C. The Subtle Effects of Language Anxiety on Cognitive Processing in the Second Language. Language Learning, 1994, 44, 283-305. http://dx.doi.org/10.1111/j.1467-1770.1994. tb01103.x

11. Brame C.J. Flipping the classroom. Vanderbilt University Center for Teaching. URL: https://cft.vanderbilt. edu/guides-sub-pages/flipping-the-classroom

12. Buran A., Filyukov A. Mind Mapping Technique in Language Learning. Proceedings Social and Behavioral Sciences, 2015., Vol. 206, 215-218 pp. Електронний ресурс. Режим доступу: http: //www.researchgate. net/publication/283983705_Mind_Mapping_Technique_in_Language_Learning

13. Orlova N.V. Efficiency of Mind Mapping for the Development of Speaking Skills in Students of Nonlinguistic Study Fields. Освіта і наука. Науково-практичний журнал Південноукраӥнського національного педагогічного університету імені К.Д. Ушинського. Одеса, 2017. № 6. С. 151-161

14. Прошьянц Н.А. Формирование иноязычных лингвистических компетенций в профессиональном дискурсе. Научно-исследоват. работа. 2010, 3. с. 34-38

15. Прудникова Н.Н. Педагогическая технология формирования иноязычной компетенции студентов неязыковых вузов: автореф. дис. ... доктора пед. наук:13.00.01. Саратов, 2007. 20 с.

16. Федоренко Ю.П. Формування у старшокласників комунікативної компетенції в процесі вивчення іноземної мови: автореф. дис. ... канд. пед. наук: 13.00.04. Луцьк, 2005. 20 с.

17. Шавровська Н.В. Використання синергетичного підходу у діяльності викладача вищого навчального закладу. Актуальні питання теорії та практики психолого-педагогічної підготовки майбутніх фахівиів: матеріали всеукраїнської науково-практичної конференції, м. Хмельницький, 24-25 квітня. 2014 р. Хмельницький, 2014. С. 125-126.

18. Left Brain vs. Right Brain Function in Learning. URL: http://funderstanding.com/brain/left-brain-vsright-brain-function-in-learning/

\section{REFERENCES}

1. Orlova N.V. (2020). Contsept tryvoshchnosti yak psykhologichnyi atrybut vyvchennya inozemnoiy movy [The concept of anxiety as a psychological attribute of foreign language learning]. Proceedings of the International scientific and practical conference "Linguistic personality: linguistics and linguodidactics". (c. 322-325). Kyiv-Cherkasy. [in Ukrainian]

2. Spielberger C. D. (1972). Anxiety: Current trends in theory and research. N.Y.

3. Horwitz, E. (2001). Language anxiety and achievement. Annual Review of Applied Linguistics, 21, 112-126. doi:10.1017/S0267190501000071 [in English]

4. Hymes, D. (1979). On Communicative Competence. C.J. Brumfit \& K. Johnson (eds.). The Communicative Approach to Language Teaching. London [in English]

5. Hlukhovska N.A. (2016). Formuvannya inshomovnoiyi kompetenzii studentiv tekhnichnykh spezialnostey VNZ Ukrainy agrarnoho profiliu [Formation of foreign language competence of students of technical specialties of Ukrainian universities of agricultural specialisation]. Current issues of pedagogy, psychology and vocational education, 1 . http://journals.uran.ua/apppfo [in Ukrainian]

6. Onufriieva I.L., Onufriieva L.A. (2011). Psykhologichni osoblyvosti Formuvannya inshomovnoiyi komunikatyvnoyi kompetenzii studentiv - maibutnikh vypusknykiv nemovnykh spezialnostey VNZ 
[Psychological features of formation of foreign language communicative competence in students as future university graduates of non-linguistic specialties]. Проблеми сучасної психологї̈, 12, 727-739 [in Ukrainian]

7. Pantelieieva O.O., Malieieva T.Ye. (2019). Formuvannya inshomovnoiyi komunikatyvnoyi kompetenzii studentiv nemovnykh spezialnostey [Formation of foreign language communicative competence of students of non-language specialties]. Spirituality of personality: methodology, theory, practice, 1(88), 132-142. [in Ukrainian]

8. Passov Ye.I. (1991). Kommunikativnyy metod obucheniia inoayzychnomu govoreniiu [Communicative method of teaching foreign language speaking]. 2 ed. M.: Prosvescheniie. [in Russian]

9. Eysenck, M. W. (1979). Anxiety, learning, and memory: A reconceptualization., Journal of Research in Personality, Volume 13, Issue 4, 1979, 363-385, https://doi.org/10.1016/0092-6566(79)90001-1 [in English]

10. MacIntyre, P. D., \& Gardner, R. C. (1994). The Subtle Effects of Language Anxiety on Cognitive Processing in the Second Language. Language Learning, 44, 283-305. http://dx.doi.org/10.1111/j.1467-1770.1994. tb01103.x [in English]

11. Brame C.J. (2013) Flipping the classroom. Vanderbilt University Center for Teaching. URL: https:// cft.vanderbilt.edu/guides-sub-pages/flipping-the-classroom

12. Buran, A., Filyukov, A. (2015). Mind Mapping Technique in Language Learning. Proceedings of the conference "Social and Behavioral Sciences". Vol. 206, 215-218. URL: http://www.researchgate.net/ publication/283983705 Mind_Mapping_Technique_in_Language_Learning [in English]

13. Orlova N.V. (2017). Efficiency of Mind Mapping for the Development of Speaking Skills in Students of Non-linguistic Study Fields., «Science and Education» Academic Journal of South Ukrainian National Pedagogical University named after K.D. Ushinski, 6, 151-161.

1. https://doi.org/10.24195/2414-4665-2017-6-23 [in English]

14. Proshiants N.A. (2010). Formitovaniye inoyazychnykh lingvisticheskikh kompetentsiy v professionalnom diskurse [Formation of foreign language linguistic competencies in professional discourse]. Scientific research work. (c. 34-38). [in Russian]

15. Prudnikova N.N. (2007). Pedagogicheskaya tekhnologia formirovaniya inoyazychnoi kompetentsii studentov neyazykovykh vuzov [Pedagogical technology for the formation of foreign language competence of students of non-linguistic universities]. Abstract of the doctor of pedagogical sciences dissertation. [in Russian]

16. Fedorenko Yu.P. (2005). Formuvannya u stashoklasnykiv komunikatyvnoyi kompetenzii v protsesi vyvchennya inozemnoiyi movy [Formation of communicative competence in senior school students in the process of learning a foreign language]. Abstract the candidate of pedagogical sciences dissertation. [in Ukrainian]

17. Shavrovska N.V. (2014.) Vykorystannia synergetychnoho pidkhodu u diyalnosti vykladacha vyschoho navchalnoho zakladu [The use of a synergetic approach in the activities of a university teacher]. Proceedings of the all-Ukrainian scientific and practical conference "Current issues of theory and practice of psychological and pedagogical training of future professionals", 125-126. [in Ukrainian]

18. Left Brain vs. Right Brain Function in Learning. URL: http://funderstanding.com/brain/left-brain-vsright-brain-function-in-learning/ 